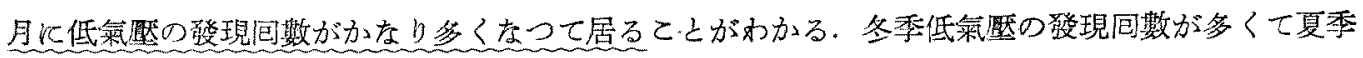

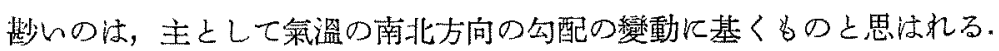

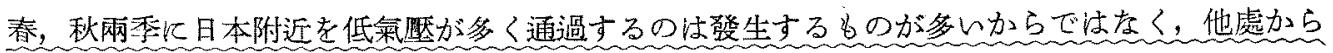

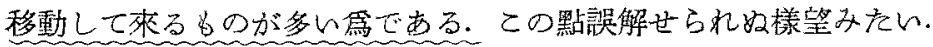

\title{
§2. 日本附近における低氣壓の進行
}

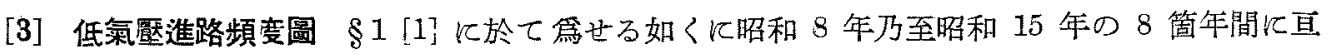
り緯度及び經度 $2^{\circ}$ 每の區劃內を通つた低氣壓の回數を數へて表示したのが第 3 圖でする。第 3 圖

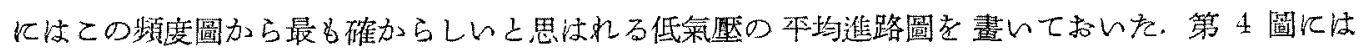
低氣塺通過頿度を色別けにして示してする。

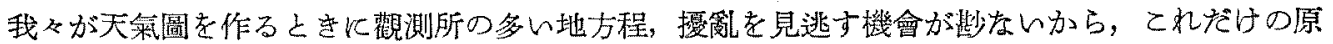
因で为低氣厴汁陸地近くを通るやうにも見へるか子知れない。しかし第4 圖から見られる如く

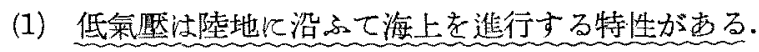

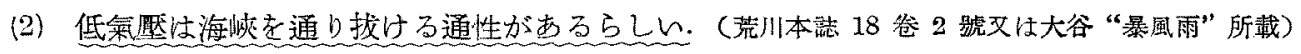

[4] 低氮壓の進行方向 著者の1人（荒川）は嘗て山烟，川本兩E ${ }^{(1)}$ V囑して日本附近の低氣壓

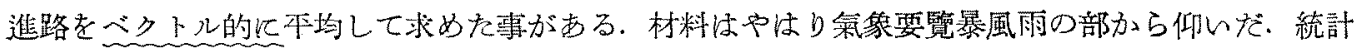
年數注昭和 10 年から 12 年迄 3 筒年である. 第 5,6 圖には夫ぬ 1 月及び 7 月の低氣㕎の進行 方向及び速度が圆示してある. ベクトルの矢の向きは平均進行方向を示し，ベクトルの長さは本均

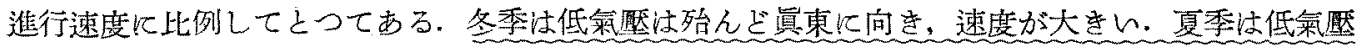

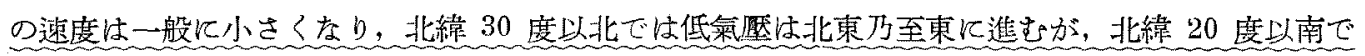

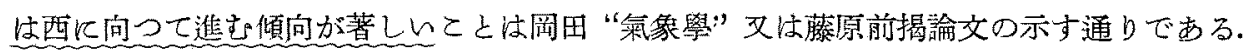

本文を草するに當り大谷學见の援助を得を．記して深謝する。

本邦に於ける季艒の天候豫想に就いで 高 橋 浩 一. 郎

1.はしがき 季節の天氣豫想は特に農業と關聯して昔から切實に要求されてるた。そしている らろの試みが行汒れたが未だ充分の結果は得て居ない，例へば現在最も實用的であり，且多少法成

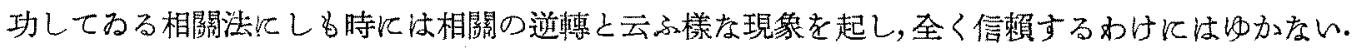
元來 1 月も 2 月も先の天氣を豫想し上引と云ふのが無理な要求ではするが，一䝫年夏季の中國，九

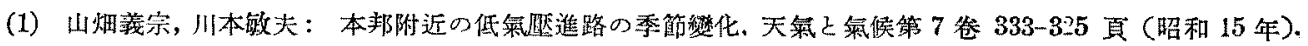

* K. Takahasi : On the Seasonal Forecast in Japan. 中央氣象瞢器報. 
州の大旱魀, 一昨年冬から昨年梅雨にかけての東海道, 關東に於ける異常の早天續きに會ひ, 文現

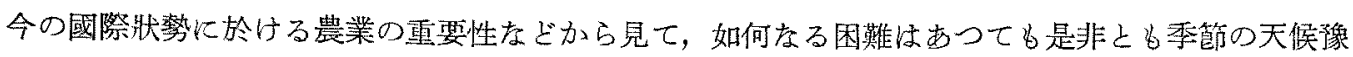
想を砸究しててく必要がある。樣感亦る。

さて現在行汢れておる天候豫想方法汉幾つかむるが，それ等の缺點はいづれ占皮相的であり，充 分天候の性筫を研究しそれに基づいた方法が案外少い事の樣である. 本邦に於いては既に古典的と

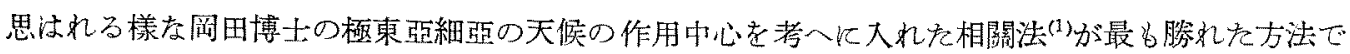

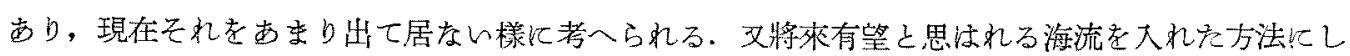

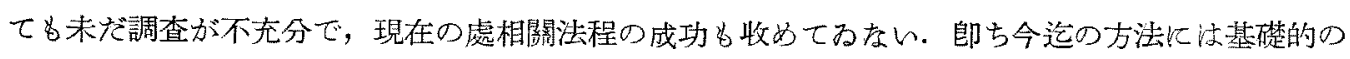
研究が足りないのである、例人ば相閶法と於ける冬季の作用中心を考入るとしても單に每日の天氣 變化から推して，冬季本邦の天候を左右するの法シべリヤの高氣然として各地との相關老計算して

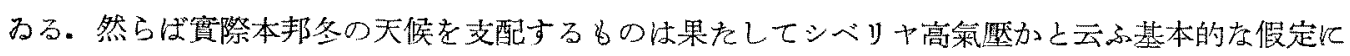

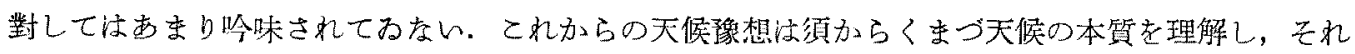
に基づいて行はなければならない樣に感ずる。乙れ海單に筆者一個の考入でをく，世界的比この樣

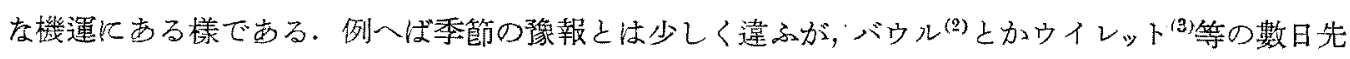
の天候豫想を見る上，多分に天候の機構に立入り，大氣の大循環を基にして統計的方法で分析して わるのである.

2. 季篇の天候豫想に重要視さるべき氣象要素 我及汶天候豫想の具體的の問题に立大る前に， 天候嶑想をするのに汁如何なる要素を探つをならば良いか，又如何なる方針の基江考へを進めをな らばよいかを少しく考察して見る必要があると思はれる。我々が天氣豫報で行つて居る方法を分析 して見ると多くは所謂保在性の大きな要素をとり，その要素を時間的に文空問的に外插して居る. 例へば日常廣く使用されて居る等瘆線飞依る天氣豫報にしても高氣壓とか低氣壓とか及注不連續線 の樣な特徵する點を㨔へ，前の動きから將來の狀況を刵斷するのですつて，この際必然的にそれら

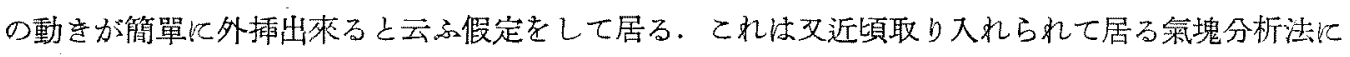
就いても同じである。なるへく保在性の大きな濕球溫度とか，相當溫位とかが氣塊分析䘮行る際の 最上の要素とされて居る.

天候の豫想にも同じ事が云へると思壮れる. 然からば1月とか 2 月上か云ふ樣な長期のbのに對 しては如何なる要素が最多保在性がある价らうか。これを調べる意味で各月の本均氣溫, 平均氣厴,

(1) T. Okada: Some researches in the centers of action of the atmosphere in the Far $\mathrm{E}$ ist. 中央氯缘臺歐交報告, 第 1 能, 第 4 號.

(2) F. Baur: Die Bedeutung der Stratosphäre für die Großwetterlage. Met. Zeit. 53, 237, 1936.

(3) Willet and Others: Report on an Experiment in Five-day Weather Forecasting. Pap. Phys. Ocean. Met. M. I. T. 8, 3, 1940. 
總隆水量をより相續く月の値の相關を調べて見を. その結果が次表で，相績く月の氣溫は比較的大 きな相關があるが，氣厴，降水量注割合小さく殊 飞降水量汢㱠んど相關が認められない。この相閣

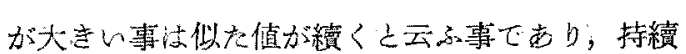

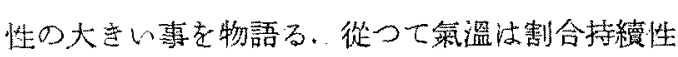
があるが，他の要素恃むまり巵い事になる。これ は氮然を主としてるる日《の天策の場合之汁大分

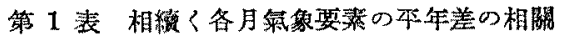

\begin{tabular}{|c|c|c|c|c|}
\hline & & 氣温平知差 & 氧崖厌年差 & 總降水量 \\
\hline 新 & 景 & 0.49 & -0.01 & -0.16 \\
\hline 资 & 夌 & 0.48 & 0.02 & 0.09 \\
\hline 父 & 梍 & 0.45 & 0.02 & -0.06 \\
\hline 紗 & 那 & 0.31 & 0.34 & -0.05 \\
\hline 漠 & 9 & -0.08 & -0.27 & 0.01 \\
\hline
\end{tabular}

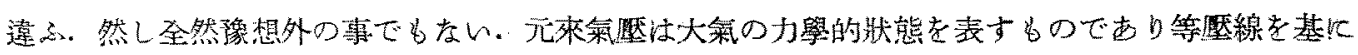

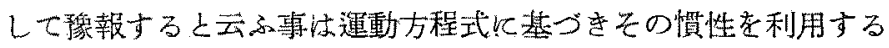
のである。然るに大氣の擘擦に依る運動エネルギーの消耗汢かな り大きく，若しエネルギーの補給がなければ一兩目で地球上に於 ける大氣の大循環嵉つてしまふであらう。

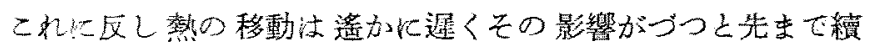

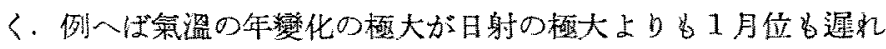
る如き度その良い例で，地面の中 10 米位移動するのでさへ1年

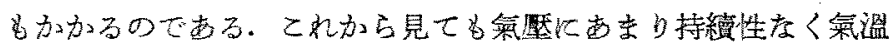
に持續性が大きい事杜容易比うなづける。

さて持䌁性が大きい事は變化が連續的ですり，外捙が可能な事

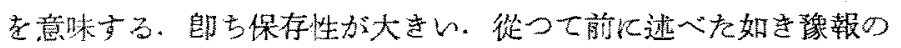
一般的方針から見て天候老豫想する場合の要素としては熱の流れ

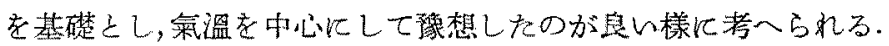

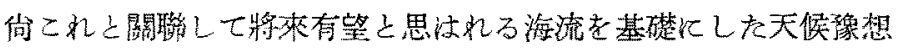

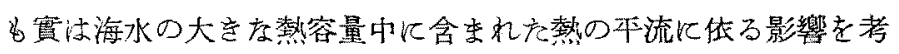

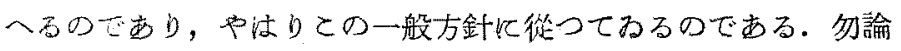

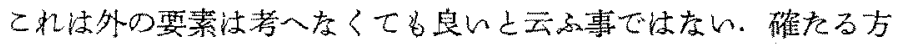

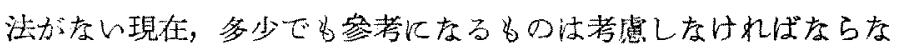
いが，その中最も重要視されるのが熱を基礎とした方法であると 云ふののでる.
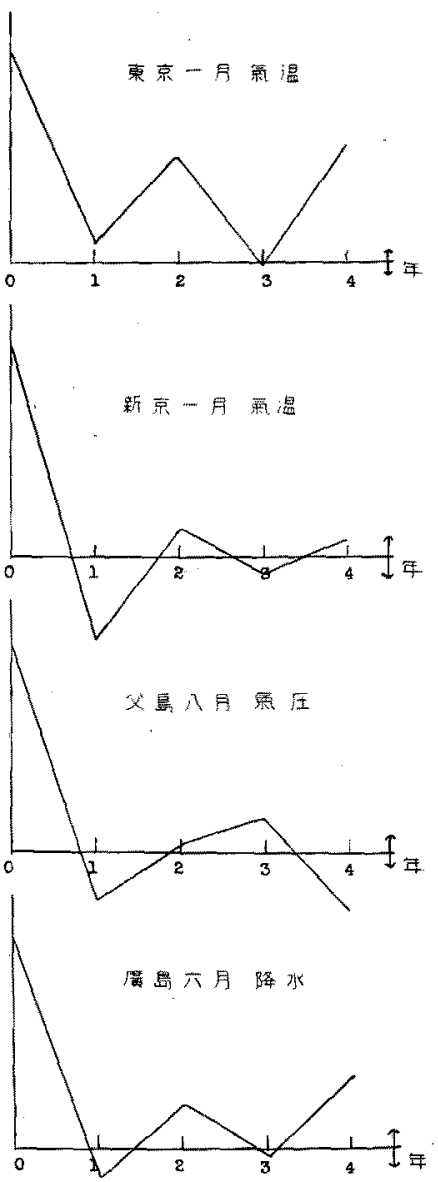

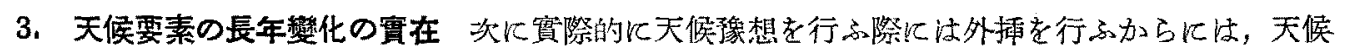

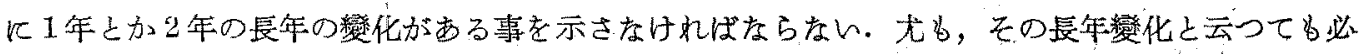
高しも連纈した每月の值が連續的に變らなくと当良い，天侯を支配する何等かの要素儿簡單に外捙 
が出來る變化があれが良いのである．氣盜とか氣壓の年平均值の樣なものを取报つてるると二次的 原因に依り一次的の原因が隱されてしまふ事がある。例人ば次の樣な事が考へられる。地球上の氣 温法太陽の日射に依り支配される，日射が强くなると一般に氣溫汁高くなる管で，氣溫を調べる事

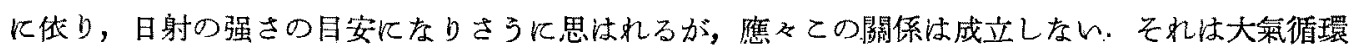
が效いてくるからである、日射が强くなると大氣循環が盛んになり本邦の氣溫恃夏流くなるが， 冬仕反對に低くなる，從つて氣溫の年平均をとつたのではこの二つの影響が互ひに打消しあひ，日 射の强さの變りに依る大氣活動の變化沈むまり出ててない. 從つてての樣な際の大氣活動の變化は

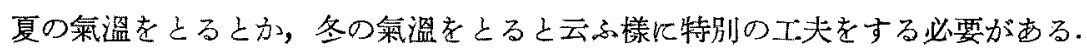

現在の所實際の天候の長年變化支配する第一次の因子之云るの汒ハンフリースの火山爆發化依 つて吹き出される灰に依り日射が變ると云ふ樣な說がないではないが,(1) 確定的の事㤌判らない.

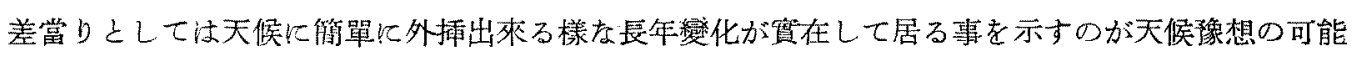

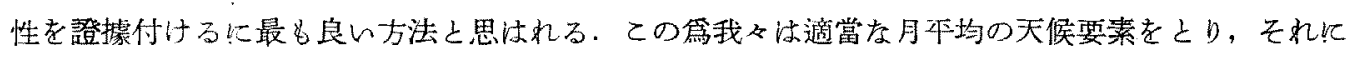
ついて週期性とか持續性と云つた樣なものを調べて見よう。

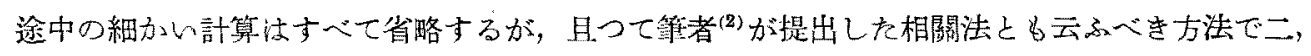
三の天候要素について週期性や持續性を分析して見を結果を示寸之圖の如くである. 圖中の矢核誤 差の程度を示したもので，乙れを見ると明かに 2 年週期の變化が認められる。乙の原因が何處に亦

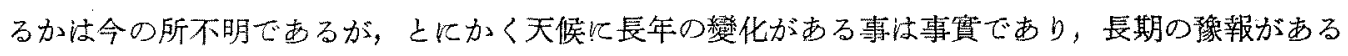
程度迄注可能の樣でる。

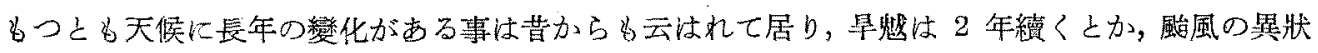
進路も2，3 年繼續しておてるらしいとは良く聽く事である.しかしそれは多くは單なる經驗に依 るものでむり，分析の方法が不確實でいささか疑問がないでもなかつた，しかし今包の分析化り 長年變化が㐫る事が略ミ確實に結論されれ樣に思はれる。

4. 冬の天候の本性とその豫想 以上を前提として我ねは最名機構が簡挐と思はれる冬の天候か

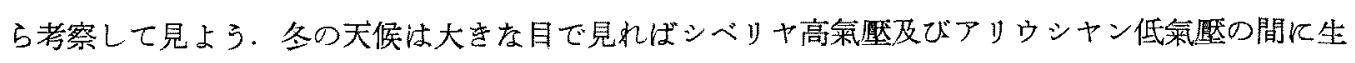
じた低氣厴傾度に依り，シベリヤ大陸から寒冷な氣塊が吹き出す現象に外ならない.(3) この氣遮傾 度が急になると季節風が强くなり，裹日本法天氣が惡くなるが表日本な反對住良くなる：ての樣な 考へから冬の天候のいろいるの性質が說明出來る.

例へばいるいる調べて見ると內地の氣溫と大陸の氣溫とは相㖹に良い相關がある. 冬季 1,2 月

(1) Humphreys: Physics of the Air, 556-629

（2）振動體の不規則な振動上り其の䓢期减変比を求める方法. 應用物理，7，昭和 13 年.

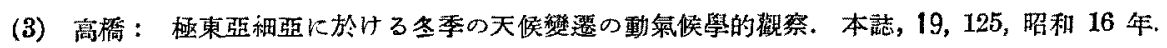


の東京と新京の氣溫では $0.80 \pm 0.12$ の相關があり, 又新京と父島でも $0.53 \pm 0.19$ の值を有して居

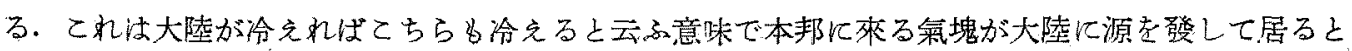

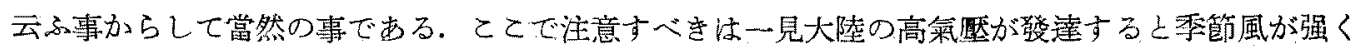

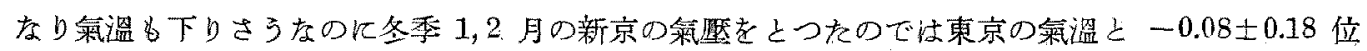

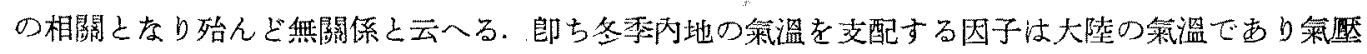
では校い事になるのである。

次に表日本の代表として東京の冬季 1，2 月の總降水量を支配しさうな幾つかの因子をとり，そ れらの間の相閣係數を勘定して見ると次の如くである.

これで氣がつく事は大陸の氣温

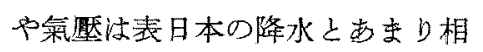
關がをい事である。乙れ注我々の 今迄の感じと大分違ふ.

·果京冬季の降水量上相閵声る。

\begin{tabular}{|c|c|c|c|}
\hline 新京氣波 & 八美氣溫 & 紗郡雨原 & 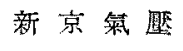 \\
\hline $0.14 \pm 0.12$ & $0.65 \pm 0.16$ & $0.48 \pm 0.18$ & $0.08 \pm 018$ \\
\hline
\end{tabular}

表日本の降水を支配するもの注この表から推して內地南方の溫度とアリウシヤンの低氣层之考入 られる. この事名前述の冬の天候の本澌から當然の歸結である. 表日本の雨㳉內地の南方海面の暖 氣塊から補給されるのであり，それが暖かければ空氣中に多くの水分を含み從つて降水量は增す。 これ八丈島の氣溫之東京の降水量とが相關ある由緣でする。しかしてれだけが東京の降水を支配す る唯一の因子ではない。

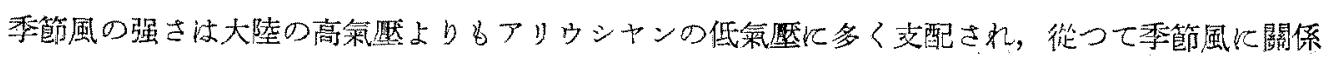
する內地の天候も著るしくアリウシヤン低氣唯の影蓄を受ける，乙の樣な意味から冬李表日本の天 侯を支配する因子はアリウシヤンの低氣壓ですり，作用中心汁今迄我ふが考へて居を樣にシベリヤ である上はさう簡單に云八ないのである。

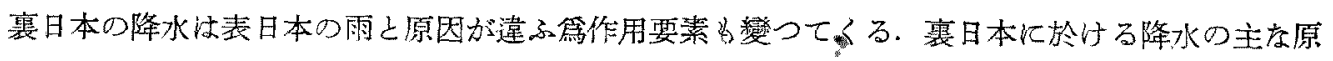

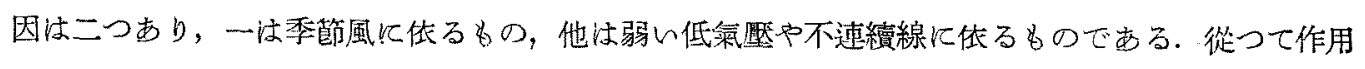

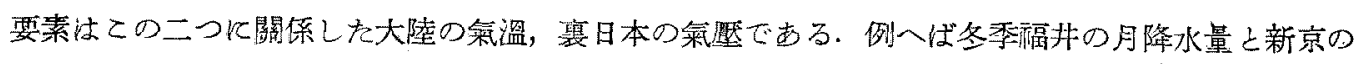
同じ月の氣溫及び新渴の氣㼟との相閵を計算して見ると $-0.30 \pm 0.18 ，-0.35 \pm 0.18$ となりこの邊 りの渻息を物語る。

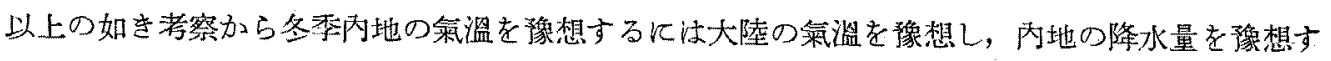
るにはアリウシャンの低氣㻺の動向を豫想するのが第一義的であるのが制かる、もつともこれは一

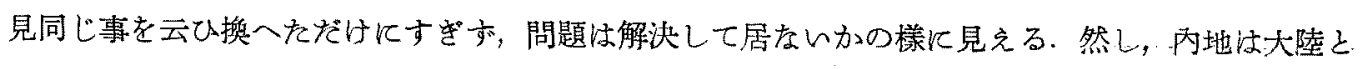

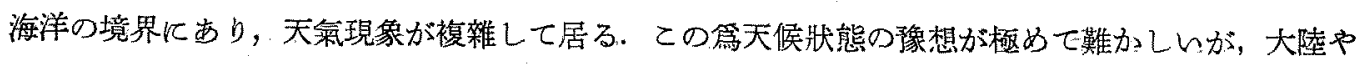

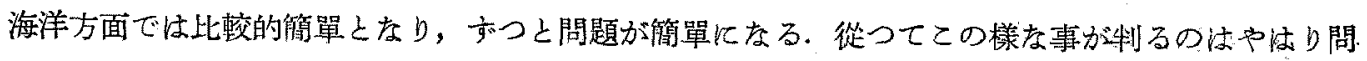


題の解決への一步となるのである.

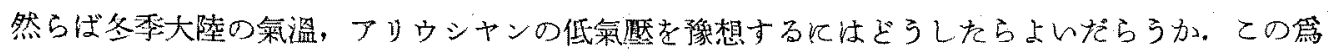
大氣循環と云ふ樣な事を頭儿入れなが新京の1，2 月の氣溫といろいるな因子の閒の相關係數を 勘定して見た、結果を表にして見ると次の如くである.

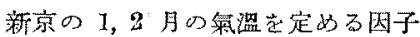

\begin{tabular}{|c|c|c|c|}
\hline 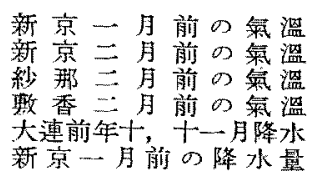 & $\begin{array}{r}0.58 \pm 0.16 \\
0.53 \pm 0.14 \\
0.40 \pm 0.18 \\
0.39 \pm 0.18 \\
-0.56 \pm 0.15 \\
-0.25 \pm 0.18\end{array}$ & 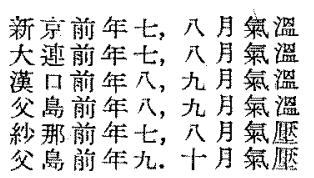 & $\begin{array}{r}-0.43 \pm 0.18 \\
-0.52 \pm 0.17 \\
0.40 \pm 0.18 \\
0.55 \pm 0.17 \\
-0.20 \pm 0.18 \\
0.48 \pm 0.16\end{array}$ \\
\hline
\end{tabular}

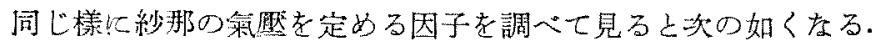

紗刜の 1，2月の氮然起定める因子

\begin{tabular}{|c|c|c|c|c|}
\hline 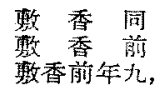 & 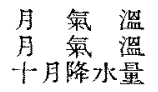 & $\begin{array}{r}-0.58 \pm 0.14 \\
0.22 \pm 0.18 \\
0.29 \pm 0.18\end{array}$ & 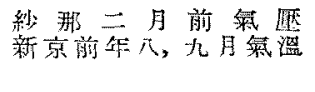 & $\begin{array}{r}0.48 \pm 0.18 \\
-0.42 \pm 0.15\end{array}$ \\
\hline
\end{tabular}

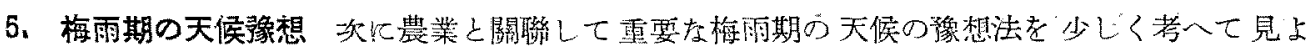
う. 元來梅雨現象之云ふのは極東に特有な季節の變り目に起る複雜な天氣現象ですり，その機構も 簡單にはかをづか交い。しかし極く大雜把に見るとオホック海高氧厴から吹き出す冷をい氣塊と

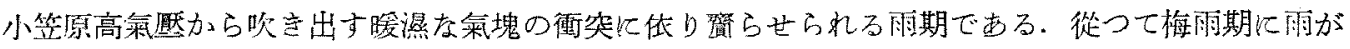

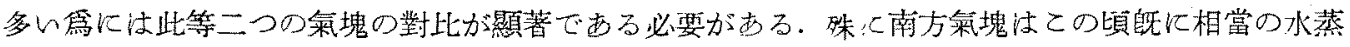

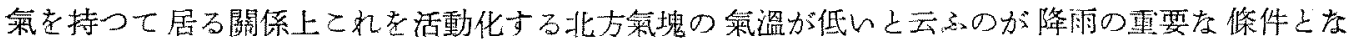
る.

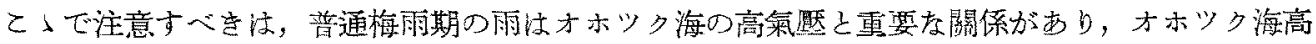
氣壓が發達する事が顯著な梅雨となる條件と考へられてるる。それでオホック海高氣厴の代表とし て 5, 6 月の紗那の月平均氣壓之東京の月降水量との相閵を調べて見ると $0.27 \pm 0.18$ 位となり，豫 想に反し僅かで沈あるがむしる反對の關係が認められるのである，勿論この事は月の值てついて云 へるのであり，每日の天氣炕閣して注オホック海高氣埾が梅雨期の雨と關聯してみるが，ての樣な

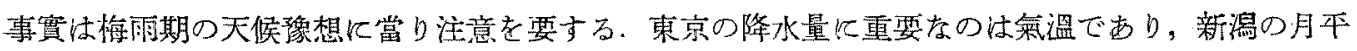
均氣擝よの相關係數索勘定して見る上 $-0.31 \pm 0.17$ となるのである.

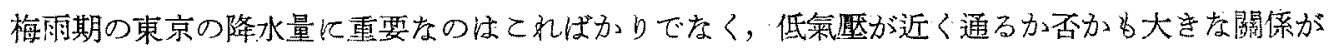

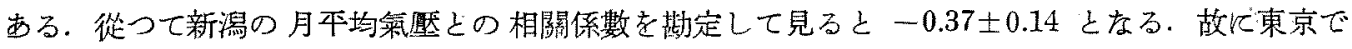

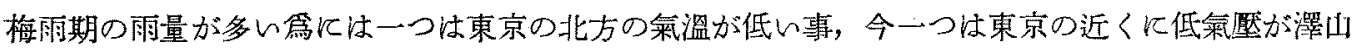
通る事であるのが制かる。 
以上法東京に關するものであるが，內地の西部の代表として廣島をとり，そての降雨炕關係する 因子を調べて見ると東京之は大分違ふ事が判かる，乙の邊りの梅雨期の降雨汢主として暖前線に上

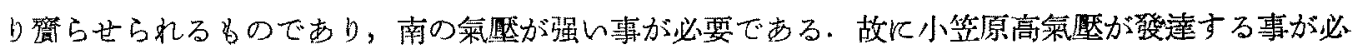

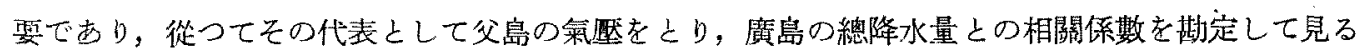
と $0.47 \pm 0.11$ となるのである.

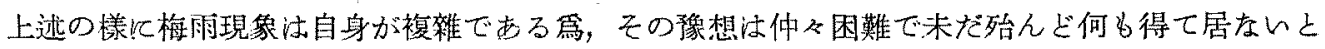
も云へる.しかし今迄得を結果で多少手探りてなる多のを次にすげて見よう.

梅雨汁一種の大氣活動の現れである故，原因汁良く制らないが，大氣の活動が盛んな時にはや汢 り梅雨名顯著にあら沈れであらう。乙んな意味から冬季の極東亞細亞の大氣活動を示す大陸の氣 溫，アリウシヤンの低氣㗛と梅雨密接な關係がありさうに思入る．それで東京の 5，6月の月降水

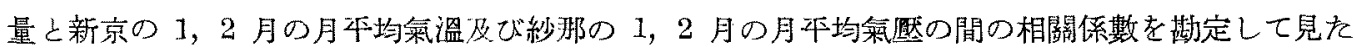

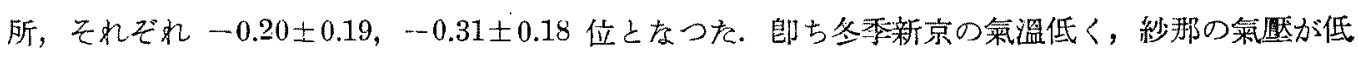

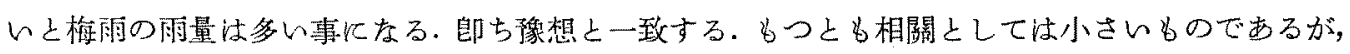

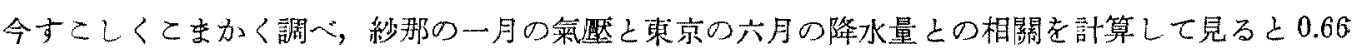

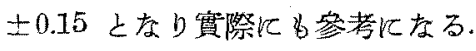

次に上に調べた結果隹ると北方氣塊の氣溫が東京の降水に閣係ある。そしててれは氣塊の運動 を追跡して見ると大陸からくる故大陸の氣溫之關係がありさう考へられる．それで同じ $5 ， 6$ 月

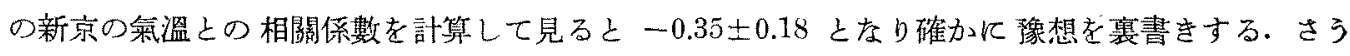
すると氣湓には持續性がある故，1月前の新京の氣溫から東京の降水量が豫想出來る筈である. 實際 1 月前の新京の月平均氣溫之5，6月の東京の月降水量之の相關係數出出して見ると一 $0.38 \pm$ 0.18 となり，確かに逆相閣があるのが認められる。

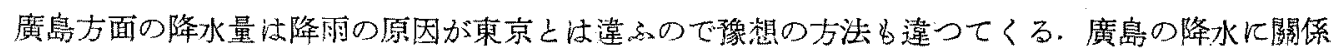

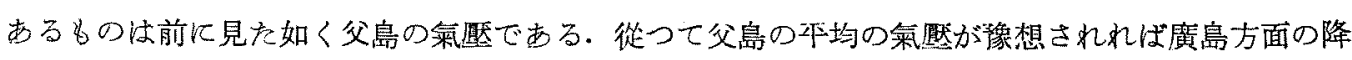

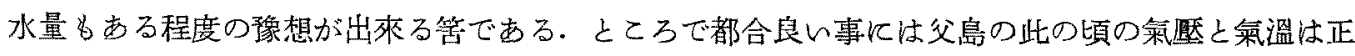

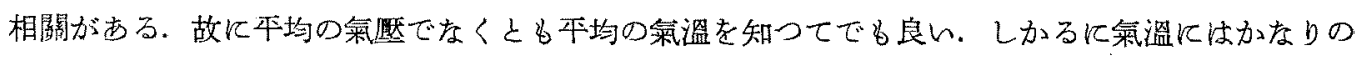
持續性がある．乙の樣炕考へて見る上 1 月前の父島の氣溫之廣島の降水量との間に法相關がある 筫でする. それて實際 6 月の廣岛の降水量と 5 月の父島の平均氣溫の間の相關係數を勘定して見

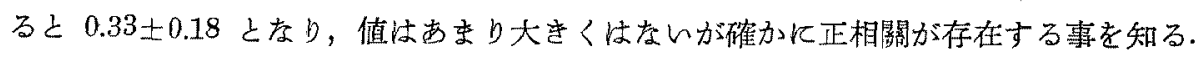

6. 結 語 現在の所到達した處注ま゙゙ての程度であり，昔の相關法と大差ない結果に終つたが， それでもいくらか注今後の見當がついて來れ樣に思へる・これからの天候の豫想には今迄の樣な手 探り式の方法では最早だめである，季節の天候をよく理解しそれに應じを方法をとらなければいけ 
ないであらう，乙の問題は重要なので今後な恢考察をつづけ度いと思つて居る.

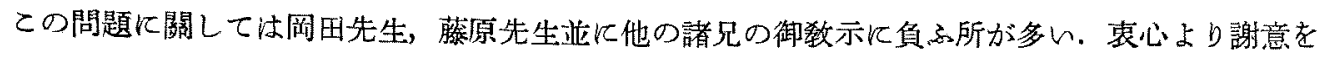
表する.

\section{高橋喜彥氏の方法に依る波動方程式の一數値的解法*}

本間 正 作

\section{1. 緒言}

最近, 高橋喜彥氏汢「熱及び瀜動傳導の圖式解法」と題する諭文を發表され, ${ }^{(1)}$ 極めて巧妙な圖 式積分飞传り，種々の境界條件の下に熱傅導方程式を解き，更と進んで寒暖二氣塊の混合過程及び

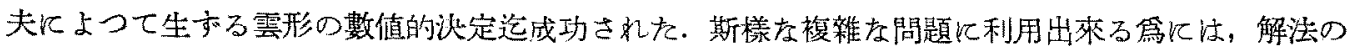
手續きが成る可く简易である事が重要な條件となるが，此の方法汢その點に於て著しい特長を持つ

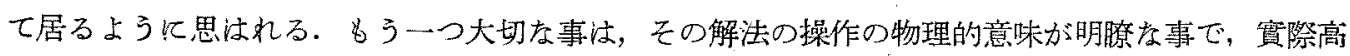
橋氏汢物理的考察に基いて解法を得られた事を說いて居られ，又藤原博士が指示された通りに，同 博士の稱へられた向仨等原理 ${ }^{(2)}$ 一方面に證明を與へた事になつてわる.

一方, 波動現象の中に夕重要でむるが椱雜で近付き難い問題が澤山殘されて居るから，高橋求上 同じ樣な方法で波動方程式が解ければ非常化便利な筈でする.今包汢，その方法の物理的內容及び 日高博士に傸つを登明を述べ，又圖式積分の代り飞數值積分を用ひる場合に便利な形への變換及び， 實用性を確か的る䉆の簢單な一例を記した。

\section{2. 第 1 の方法及びその物理的意味}

先づ一㧼な媒質內に於ける一次元の波動

$$
\frac{\partial^{2} u}{\partial t^{2}}=\nabla^{2} \frac{\partial^{2} u}{\partial x^{2}}
$$

を考へる. 或る時刻 $t$ K於ける波動の場の模樣が分つて居る時, 極めて短い時閒 $\tau$ の後の $u$ の值 は $0\left(\tau^{3}\right)$ 無視出來るものとすれば，次の如くなる。

$$
u(x,+\tau)=\frac{1}{2 \gamma^{\overline{3}} V_{\tau}} \int_{-\sqrt{3} V \tau}^{\sqrt{3} \nabla \tau} u(x+\xi, t) d \xi+\tau \cdot \frac{\partial u(x, t)}{\partial t} .
$$

* S. Honma : Application of Y. Takahasi's Method to the Integration of the Wave Fquations.

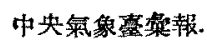

(1) 本誌, 第 19 能, 第 8 㩆.

（2）藤原吹平：大氮物理學 (岩波橴座; 物理學及化學), p. 126 